\title{
Resistance to change, work engagement and psychological capital of academics in an open distance learning work environment
}

\begin{tabular}{|c|c|}
\hline \multicolumn{2}{|c|}{$\begin{array}{l}\text { Authors: } \\
\text { Johanna C. Diedericks }{ }^{1} \text { (I) } \\
\text { Frans Cilliers }{ }^{2} \text { (D) } \\
\text { Adéle Bezuidenhout }^{1} \text { (D) }\end{array}$} \\
\hline \multicolumn{2}{|c|}{$\begin{array}{l}\text { Affiliations: } \\
{ }^{1} \text { Department of Human } \\
\text { Resource Management, } \\
\text { University of South Africa, } \\
\text { Pretoria, South Africa }\end{array}$} \\
\hline \multicolumn{2}{|c|}{$\begin{array}{l}{ }^{2} \text { Department of Industrial } \\
\text { and Organisational } \\
\text { Psychology, University of } \\
\text { South Africa, Pretoria, } \\
\text { South Africa }\end{array}$} \\
\hline \multicolumn{2}{|c|}{$\begin{array}{l}\text { Corresponding author: } \\
\text { Johanna Diedericks, } \\
\text { diedejc@unisa.ac.za }\end{array}$} \\
\hline \multicolumn{2}{|c|}{$\begin{array}{l}\text { Dates: } \\
\text { Received:13 Nov. } 2018 \\
\text { Accepted: } 19 \text { Sept. } 2019 \\
\text { Published: } 12 \text { Nov. } 2019\end{array}$} \\
\hline \multicolumn{2}{|c|}{$\begin{array}{l}\text { How to cite this article: } \\
\text { Diedericks, J.C, Cilliers, F., } \\
\text { \& Bezuidenhout, A. (2019). } \\
\text { Resistance to change, work } \\
\text { engagement and } \\
\text { psychological capital of } \\
\text { academics in an open } \\
\text { distance learning work } \\
\text { environment. SA Journal } \\
\text { of Human Resource } \\
\text { Management/SA Tydskrif vir } \\
\text { Menslikehulpbronbestuur, } \\
\text { 17(0), a1142. https://doi.org/ } \\
\text { 10.4102/sajhrm.v17i0.1142 }\end{array}$} \\
\hline \multicolumn{2}{|c|}{$\begin{array}{l}\text { Copyright: } \\
\text { (C) 2019. The Authors. } \\
\text { Licensee: AOSIS. This work } \\
\text { is licensed under the } \\
\text { Creative Commons } \\
\text { Attribution License. }\end{array}$} \\
\hline \multicolumn{2}{|l|}{ Read online: } \\
\hline 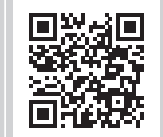 & $\begin{array}{l}\text { Scan this QR } \\
\text { code with your } \\
\text { smart phone or } \\
\text { mobile device } \\
\text { to read online. }\end{array}$ \\
\hline
\end{tabular}

Orientation: In the present knowledge economy, the external environment is rapidly evolving and organisations are increasingly demanding much more from their employees. Psychological capital (PsyCap) and work engagement (WE), seen as positive human resource strengths and psychological capacities, can be developed and effectively managed for enhanced work performance. Employees' resistance to change (RTC) is a key barrier to organisational change.

Research purpose: To investigate the interrelationships between PsyCap, WE and RTC of open distance learning (ODL) academics.

Motivation for the study: Little empirical research has investigated the application of positive work and organisational psychological functioning of ODL academics. Universities can use the study results to develop strategies which may enable institutions and individuals to flourish through positive well-being despite change.

Research approach/design and method: A quantitative survey including a probability sample of $208(N=208)$ academics was utilised. Structural equation modelling was used to analyse the data.

Main findings: The results reveal a meaningful positive relationship between the positive psychological constructs of PsyCap and WE, and a meaningful negative relationship between the psychodynamic construct RTC, and the positive psychological constructs of PsyCap and WE. Structural equation modelling indicated an adequate fit of conceptual structural model.

Practical/managerial implications: Results suggest that reduced RTC and increased positive psychological behaviour could contribute to a positive organisation and individual well-being in a changing work environment.

Contribution/value-add: This study adds to the body of knowledge and insights into positive work and organisational functioning of academics in a changing ODL work environment.

Keywords: positive work and organisational psychology; academics; open distance learning; resistance to change; work engagement; psychological capital; flourishing; well-being; positive organisation.

\section{Introduction}

The global labour market is characterised by flexibility, rapid innovations and changes. The synergies of information and communication technology have penetrated all aspects of life, and traditional services are becoming more and more multidisciplinary, intelligent and agile (Abramovici, Göbel, \& Neges, 2015). Higher education institutions (HEIs) from all over the globe have also been confronted with complex changes and challenges (Arinto, 2013; Guasch, Alvarez, \& Espasa, 2010; Panda \& Mishra, 2007). South Africa, as part of the Global South and developing world, is required to provide education to the masses in the interest of social justice whilst maintaining standards of developed world (Leibowitz, Bozalek, Van Schalkwyk, \& Winberg, 2015).

The realities of globalisation, knowledge economy and information economy are forcing structural changes and challenges on HEIs (Cloete, 2017). To adapt successfully to the changing environment, universities need to focus on both performance and health and well-being of employees (Conley, 2007). Seale and Cross (2016) arrived at the conclusion that the internal competition for dwindling resources in South African universities and the pressure experienced by deans to 'do more with less', (Seale \& Cross, 2016, p. 1522) are adding to the complexities faced by governments and 
policy makers in ODL institutions as well as all other developing world universities. Furthermore, the redesigning of all modules and teaching for online delivery in universities because of economic sustainability models has put additional pressure on all the university systems, and especially on academics (Poalses, Joubert, Bezuidenhout, \& Nienaber, 2014). Blended learning is the educational model utilised by more and more residential universities as well as ODL institutions and is not as simple as it may seem to be for both students and academics (Cloete, 2017). Terminology such as Open Educational Resources (OERs) - freely accessible documents and media for teaching, learning, education, assessment and research purposes - and Massive Open Online Courses (MOOCs), a term proposed in 2008 by George Siemens and Stephen Downes (Rodriguez, 2013), have become part of everyday educational language.

These changes and challenges necessitate that organisations need proactive employees who are committed to high-quality performance, show initiative and regard their own professional development on high priority (Bakker \& Schaufeli, 2008). Furthermore, the changing environment in which organisations function requires flexibility and innovation in the development of employees' knowledge, skills and expertise (Avey, Reichard, Luthans, \& Mhatre, 2011). This phenomenon is forcing organisations to look for specific competencies and behaviours in employees that can adapt to changes and challenges (Salanova \& Schaufeli, 2008). Two dimensions are identified in the literature which are required for academics in South Africa to flourish (Keyes \& Annas, 2009), namely feeling good and functioning well. To adapt successfully to the changing ODL environment, universities need to focus on both performance and health and well-being of employees (Conley, 2007).

Resistance to change has undergone thorough transformation in meaning, from a systems concept to a psychodynamic construct, and as it reduces optimism and hope, it is often regarded as a primary reason for lack of change in organisations (Palmer, Dunford, \& Akin, 2009; Stanley, Meyer, \& Topolnytsky, 2005). Oreg, Bartunek, Lee and Do (2018) contemplated that a supportive work environment during any intervention enhances change-related efficacy. Similarly, Bruque, Moyano and Eisenberg (2008) indicated individuals' adaptation to a technology-induced change by increasing their efficacy. Zhongen (2015) indicated that one of the biggest challenges with regard to the effective implementation of modern, agile educational models is the unwillingness to change at institutional level.

The movement towards positive work and organisational psychology has highlighted an awareness of happiness of people in work and organisational contexts (Rothmann, 2013; Swart \& Rothmann, 2012).

Positive organisations characterised by flourishing employees enable the organisation and individual employees to flourish through positive well-being despite changes (Seligman \&
Csikszentmihalyi, 2000). Flourishing employees demonstrate positive feelings and positive functioning (Keyes, 2007) as well as hope, efficacy, resilience and optimism, and this what is termed as positive psychological capital (PsyCap). Bakker and Demerouti (2008) suggest that these personal resources facilitate work engagement (WE). Work engagement makes an important contribution to the flourishing of individuals in an organisation (Diedericks \& Rothmann, 2013).

Seale and Cross (2016) express their concern about the absence of research in the universities of the developing world such as South Africa. In this context, Kuanda (2012) calls for increased research in universities. Therefore, this study adds greatly to the body of knowledge by mainly focusing on the impact of RTC, WE and PsyCap on ODL academics and concludes with a synopsis of practical implications, study's limitations and recommendations for the future research.

\section{Literature review Open distance learning}

Technology is an integral part of living today, referred to as the fourth industrial revolution, with numerous opportunities but also extensive challenges (Cloete, 2017). In adapting to a vibrant, changing external as well as internal work environment and new developments in information and communication technology, ODL academics are becoming part of a complex process that depends on political, administrative, organisational, strategic and cultural factors. This transformation requires change resilience and dynamic interaction between the academics and complex environment (Luthar \& Cicchetti, 2000). Bates (2014) argued that ODL academics in particular faces an increasingly diverse work environment and are not developing adequate skills for the digital age. Barkhuizen, Rothmann and Van De Vijver (2014) identified the increasingly work overload as a top barrier to the enhancement of physical and psychological well-being of academics.

Open distance learning is changing roles of the student, the academic as well as the university because technology redefines what academics do and therefore implies change in a pedagogical rationale away from learning to critical thinking (Söderström, From, Lövqvist, \& Törnquist, 2012). Although the ODL university where this study was conducted emphasises that academics need to be able to adapt to transformation in the world of work, RTC amongst academics is seen as a huge obstacle in the way of the endeavours of HEIs to transform the existing higher education landscape (Palmer et al., 2009; Zhonggen, 2015). Changes in the higher education system, such as massification, low pass rates and tremendous pressure for increased research outputs (Scott, Yeld, \& Hendry, 2007), and challenges in ODL are becoming more complex. Many students who are entering this domain are younger, unemployed, looking for more affordable educational options and are often underprepared by the school system. They do not find it easy to adapt to higher education (Scott et al., 2007). Zhonggen (2015) notes that students' passive participation is another huge challenge. This potentially creates a more complex environment and 
an increased workload for ODL academics (Kearsley, 2000; Weller, 2002). Furthermore, Arinto (2013) is of the opinion that the professional development of academics in ODL is a complex process that requires continuous engagement in advanced roles and competencies. More recently, Bates (2014) has argued that academics experience lack of training in pedagogy as well as ODL training material development; they also experience the process of knowledge facilitation as complicated (Heydenrych \& Prinsloo, 2010).

Knowledge economy and information economy underline the connection between economy and education in a complex work environment. Student access to technology and technological literacy are ongoing challenging factors experienced in developing countries (Cloete, 2017). This further complicates the level of specific competencies and behaviours of academics, as not only physical access is needed but also epistemological access - the theory of knowledge - as well as computer and conventional literacy. According to Martin (2007), more money is spent on technology at universities and less on appointment and development of staff. Open distance learning academics therefore need to focus on positive psychological functioning that emphasises strengths and potential that could be expressed and realised in individual and social well-being (Wissing, Potgieter, Guse, Khumalo, \& Nel, 2014).

\section{Resistance to change}

Resistance to change is a multifaceted concept, originating as a psychodynamic construct which Lewin (1947) used to describe as the active force obstructing the efforts of change leaders. Oreg (2006) conceptualised and operationalised it as a reactive passive attitude towards change. Unconscious processes that influence health, well-being and (psychological) wellness within the organisation (Henning, 2009; Rothmann \& Cilliers, 2007) and organisational change (Golom, 2017) should therefore be taken into account. As transformation processes often mean resistance, a systems psychodynamic perspective enables an understanding of the dynamics between individuals and system elements, such as ineffective interventions (Koortzen \& Cilliers, 2002), conflict (Mayer, 2011) or decreased health and well-being (Mayer \& Surtee, 2015), which may contribute to an increased understanding of non-conscious dynamics within the individual.

Boundaries, often set by leadership in the organisation, determine what belongs or does not belong to the system (Cilliers \& Koortzen, 2005), and if individuals are unable to deal with anxiety and change in organisations, it is blocked out of the conscious mind, which largely shapes the nature of the system and leadership. According to De Vries (2009), many leaders have a 'dark side' or the 'shadow side of leadership', as leadership theories are inadequate and even fictional. Organisational dysfunction and destructive cycles are caused by narcissistic, controlling, depressive, abrasive, negativistic, hypomanic (disinhibition) charismatic and neurotic leadership styles as identified by De Vries (2009).
In the dynamic higher education environment, the organisation needs to recognise dysfunctional behaviour or leadership styles that might influence effective action, complicating relationships or causing discomfort and hamper well-being. It may motivate change, and often group interventions and understanding are critical for change processes. Structural aspects influencing change in organisations are defined as open systems, which may be explored (Greyvenstein \& Cilliers, 2012). Furthermore, for the individual employee, experiencing resistance, making the non-conscious conscious and becoming aware of our dark side, decision making is often taken back and complicated (De Vries, 2009). However, academics' acceptance of change in the work environment has been linked with positive outcomes such as improved well-being (Oreg, Vakola, \& Armenakis, 2011).

Rodda (2007) concluded that understanding the psychological and behavioural foundations of RTC is significant for working behaviour. More recent studies (Oreg, Michel, \& By, 2013; Oreg et al., 2018) have explored concepts that are related to RTC from an individual's different perspective. In this study, RTC is discussed as a multifaceted, people-centred construct, measuring individual's dispositional inclination to resist change (Oreg, 2003).

\section{Work engagement}

Work engagement is a three-dimensional construct, characterised by vigour, dedication and absorption, and is defined as a positive, fulfilling, affective and motivational state of work-related well-being (Bakker, Schaufeli, Leiter, \& Taris, 2008). Engagement is a positive energy that advances sustainable performance (Spreitzer, Lam, \& Fritz, 2010). Engaged employees have high levels of energy and are enthusiastic about their work. Moreover, they are often so immersed in their work that time flies and they have difficulty in detaching themselves from their work (Miner, Bickerton, Dowson, \& Sterland, 2015). However, WE cannot be seen as a skill that one can develop, but rather it is an affective motivational state (Spreitzer et al., 2010).

Work engagement refers to the relationship of an individual with his or her job (Schaufeli 2008, Krueger \& Killham 2005, as cited in Rothmann, 2017), and according to Saks (2011), WE requires a sense of connectedness with work environment. Research has indicated that WE has both short-term and long-term positive effects (Mauno Kinnunen \& Ruokolainen, 2007). On the other hand, Sonnentag, Mojza, Binnewies and Scholl (2008) argue that the level of engagement can have negative consequences if an employee is in a continuous state of high engagement which could lead to burnout.

According to Bakker, Albrecht and Leiter (2011), work engagement manifests in two antecedents, namely job resources and personal resources. Job resources include supervisory support, innovativeness, information, appreciation and organisational climate (Rice, 2009), and 
personal resources refer to an individual's positive psychological state of development, characterised by (1) confidence (efficacy) to take on and put in necessary efforts to succeed in challenging tasks; (2) making a positive attribution (optimism) about succeeding now and in the future; (3) persevering towards goals, and when necessary, redirecting paths to goals (hope) in order to succeed; and (4) when beset by problems and adversity, sustaining and bouncing back and even beyond (resilience) to attain success (Bakker et al., 2011, p. 7). Previous studies on WE have found that it is negatively related to intention to quit but positively related to job satisfaction and organisational commitment (Schaufeli, Bakker, \& Van Rhenen, 2008). Calitz (2013) argued that employees who are engaged in their work are likely to perform well, and may experience positive health and positive emotions. This enables them to be better equipped to address issues at the workplace, such as stress and change (Rice, 2009), to be more driven and to be key role players in helping to move the organisation forward (Krueger \& Killham, as cited in Rice, 2009).

It is important to note that positive working and organisational psychology, which appreciates human potential and facilitates psychological principles such as flourishing (WE), well-being and PsyCap, may contribute to optimising success and growth of ODL academics in this changing work environment. The literature further suggests that flourishing ODL academics are a crucial component of a positive HEI. Flourishing individuals may show hope, efficacy, resilience, optimism, engagement in work, find meaning, be motivated and experience high levels of psychological well-being in a changing work environment. Engaged employees may use resources such as optimism, efficacy, resilience and an active coping style to assist them to manage and influence their changing work environment with more success (Bakker, Demerouti, \& Burke, 2009; Luthans, Norman, Avolio, \& Avey, 2008; Van Der Walt, 2018). Flourishing employees enjoy quality of life and function optimally in their work environment and this is manifested through multidimensional indicators (Keyes \& Annas, 2009; Rothmann, 2013). The indicators of positive work and organisational psychological functioning which are important for this study include flourishing, WE, hope, efficacy, resilience and optimism, and these are all related to high levels of emotional well-being. Similarly, Bakker, Gierveld and Van Rijswijk (2006) argue that employees who use their resources optimally may score high levels of WE, efficacy, resilience and optimism, and this could contribute specifically to overall WE and flourishing.

\section{Psychological capital}

Luthans, Avolio, Avey and Norman (2007) define PsyCap as an individual's positive psychological state of development that is characterised by: (1) persevering towards goals and, when necessary, redirecting paths to goals (hope) in order to succeed; (2) having confidence (efficacy) to take on and put in the necessary effort to succeed at challenges; (3) when set back by problems and adversity, sustaining and bouncing back and even beyond (resiliency) to attain success and
(4) making a positive attribution (optimism) about succeeding now and in the future.

PsyCap, a higher order construct is characterised by an underlying common thread and shared characteristics running through each of the psychological resource capacities, (hope, efficacy, resilience and optimism) of a positive intentional striving towards flourishing and success, no matter what changes and challenges arise in the work environment (Avey et al., 2008). Similarly, Avey, Luthans and Jensen (2009) and Luthans (2002) are of the opinion that the construct of PsyCap, may contribute to employee well-being.

Although research on PsyCap is still in its infancy, it is playing an important role in predicting employees' attitudes, behaviours and performance (Avey et al., 2011). PsyCap is a cognitive state that includes the individual's beliefs and expectations with regard to a specific task or context (Avey et al., 2011). Luthans, Avey, Avolio and Peterson (2010) and Luthans, Avey and Patera (2008) indicated that face-to-face and web-based interventions showed an enhancement in an individual's level of PsyCap and can therefore be developed. What is also of importance for ODL academics is that high levels of efficacy and resilience protect employees from negative consequences that might arise from a stressful and changing work environment (Fida, Paciello, Tramontano, Barbaranelli, \& Farnese, 2015; Souri \& Hasanirad, 2011). High levels of hope, which are characterised by positive cognitive processes, such as setting challenging goals and finding ways to achieve these goals, are negatively linked to depression and positively linked to well-being (Alarcon, Bowling, \& Khazon, 2013; Inzlicht, Schmeichel, \& Macrae, 2014). Similarly, optimists are more likely to experience higher levels of well-being and lower levels of distress (Desrumaux et al., 2015).

A conceptual model encapsulating research hypothesis 1 was constructed for this study and is shown in Figure 1.

According to Weinberg and Cooper (2007), organisations need healthy and motivated employees to prosper and survive in a continually changing environment, characterised by increasing flexibility in working practices and the creation of a $24-\mathrm{h}$

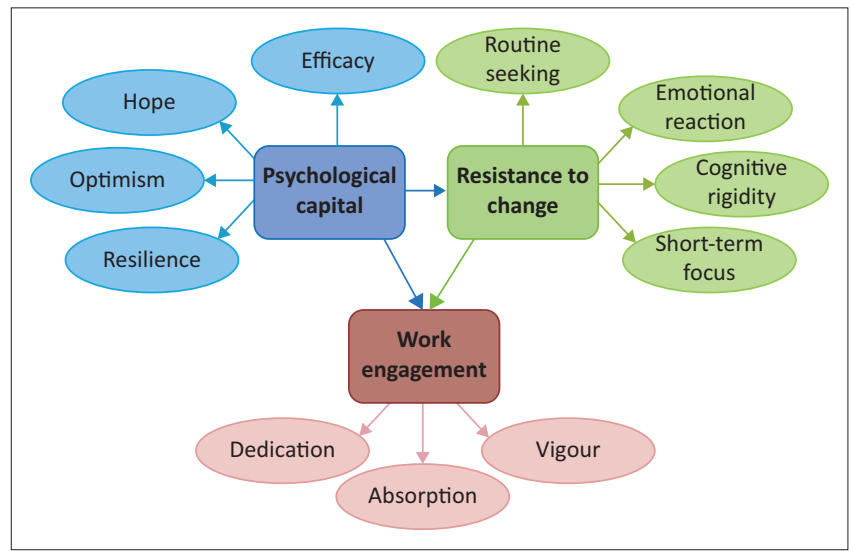

FIGURE 1: Preliminary conceptual model encapsulating research hypothesis 1. 
economy where fewer people do more work. Luthans (2002) came to the conclusion that the psychological resources that have been shown to best meet the criteria of positive organisational behaviour include hope, efficacy, resilience, and optimism. According to Beal III, Stavros and Cole (2013), little empirical research has investigated the application of positive organisational behaviour in organisations in the changing higher education environment and Youssef and Luthans (2012) suggest that the role of PsyCap in educational institutions should be investigated. From the literature it is evident that engaged employees may use resources such as optimism, efficacy, resilience and an active coping style to assist them to manage and influence their changing work environment with more success (Bakker \& Demerouti, 2008; Luthans et al., 2008). It can be seen from the model that RTC could potentially influence WE. Bakker et al. (2006) argue that employees who use their resources optimally may score high levels of WE, efficacy, resilience and optimism, and this could contribute specifically to overall WE and flourishing.

The following research hypotheses are based on the abovementioned discussion and are formulated to investigate inter-relationships between PsyCap, WE and RTC:

- $\mathrm{H}_{1}$ : There is a positive or negative relationship between PsyCap (represented by hope, efficacy, resilience and optimism) and RTC (represented by routine seeking (RS), emotional reaction (ER), short term focus (SF) and cognitive rigidity $(\mathrm{CR})$.

- $\mathrm{H}_{2}$ : There is a negative relationship between RTC and vigour (Vi)/dedication (De).

- $\mathrm{H}_{3}$ : There is a negative relationship between RTC and absorption $(\mathrm{Ab})$.

- $\mathrm{H}_{4}$ : There is a positive relationship between PsyCap (represented by hope, efficacy, resilience and optimism) and $\mathrm{Vi} /$ (De.

- $\mathrm{H}_{5}$ : There is a positive relationship between PsyCap (represented by hope, efficacy, resilience and optimism) and $\mathrm{Ab}$.

\section{Research design Research approach}

For this research, probability sampling and more specific proportional stratified sampling was used (Kerlinger, 1986; Leedy \& Ormrod, 2013). A quantitative research method was used to pursue aims of this study.

\section{Participants and sampling}

The research target population comprised 1662 permanent academics at the South African ODL university. Power analysis was conducted to estimate a target sample size for the study (Faul, Erdfelder, Buchner, \& Lang, 2009) resulting in a planned sample of 432 academics as $26 \%$ of the sample was considered to be a representative of the population. The population comprised $1662(N=1662)$ permanent academics at the ODL university and was stratified on the basis of 66 academic departments. The realised sample comprised 208 $(n=208)$ completed usable questionnaires.

\section{Measuring instruments}

An electronic survey comprising participants' demographic information and three quantitative instruments were administered to measure self-reported RTC, WE and PsyCap. The items of the instruments were scored on a six-point Likert-type scale.

\section{The Resistance-to-change scale}

Resistance to change was measured using the 17-item RTC scale (Oreg, 2006). In addition to a composite full-scale RTC construct, the RTC scale comprises four subscales: RS (five items), ER to imposed change (four items), SF (four items) and CR (four items). Previous research (Del Val \& Fuentes, 2003; Van Den Heuvel \& Schalk, 2009) indicate strong internal consistency and reliability for the full RTC instrument. Beal III et al. (2013) report on using the instrument with a sample of government organisation employees and found similar strong internal consistency reliability for full instrument ( $\alpha=0.89$ ) and the four subscales (RS, $\alpha=0.78$; ER, $\alpha=0.94$; SF, $\alpha=0.93$ and CR, $\alpha=0.65$ ) as well as acceptable construct validity. The RTC instrument also showed acceptable construct validity as evaluated via second-order confirmatory factor analysis (CFA). The overall model fit was $\chi^{2}=162.94$; $d f=114 ; p<0.01$; root mean square error of approximation (RMSEA) $(90 \% \mathrm{CI})=0.07(0.04-0.09)$; and comparative fit index $(\mathrm{CFI})=0.93$ (Beal III et al., 2013). The standardised root mean residual (SRMR) value was 0.0862 , slightly above the suggested threshold of 0.08 .

\section{The Utrecht work engagement scale}

Work engagement was measured using the 17-item version of the Utrecht work engagement scale (UWES) (Schaufeli \& Bakker, 2003). The UWES includes three dimensions, namely $\mathrm{Vi}$ (six items), De (five items) and Ab (six items).

Storm (2002) and Storm and Rothmann (2003) reported Cronbach's $\alpha$ coefficient for $\mathrm{Vi}=0.78, \mathrm{De}=0.89$ and $\mathrm{Ab}=0.78$ in a sample of 2396 employees of the South African Police Service. In an insurance company in South Africa, Coetzer and Rothmann (2007) found Cronbach's a coefficient for $\mathrm{Vi}=0.80, \mathrm{De}=0.87, \mathrm{Ab}=0.69$. Coetzee and De Villiers (2010) obtained Cronbach's $\alpha$ coefficient for Vi and De as 0.77 and 0.88 , respectively, in a financial institution (De Waal \& Pienaar, 2013).

As Cronbach's $\alpha$ coefficient of 0.7 or more is considered to indicate a reliable scale (Nunnally \& Bernstein, 1994; Pallant, 2010), the overall alpha coefficient and those for four subscales were deemed to be adequate in this study and no item-reliability analysis was conducted (Terre Blanche \& Durrheim, 2002).

\section{The Psychological Capital Questionnaire (PCQ-24)}

Psychological capital was measured using the 24-item PCQ (Luthans et al., 2007). The PCQ-24 has demonstrated adequate psychometric properties in several samples (Avey et al., 2008; Luthans et al., 2007). In addition to a composite full-scale 
construct, the PCQ-24 measured the following four subscale constructs: hope (six items), optimism (six items), resilience (six items) and efficacy (six items). The results of a series of higher-order CFAs provided strong evidence for the higherorder factor structure for the overall PsyCap measure (i.e. $\mathrm{RMSEA}=0.046 ; \mathrm{CFI}=0.93, \mathrm{SRMR}=0.051$ ) as reported by Luthans et al. (2007).

\section{Research procedure and ethical considerations}

The research procedure involved inviting research participants to complete an electronic survey administered via the Lime survey interface at the university. Information regarding the aim of the questionnaire, aim of the use of data as well as confidentiality of the information obtained was given to all respondents. Participation in this study was voluntary and all information was treated as anonymous with high regard to respondents' confidentiality. Ethical clearance for this research was obtained from the HEI. The raw data were captured and analysed using the statistical programmes Statistical Package for Social Sciences (SPSS, 2003), version 22.0 for the Microsoft Windows platform, and AMOS, version 23 (Arbuckle, 2006), for further analysis.

\section{Construct validity and reliability}

The three instruments used in this study are established measuring instruments and CFA; these were first conducted to establish model fit to the data. If an inadequate fit was found, exploratory factor analysis (EFA) was conducted to confirm the underlying factor structure of the data. For all EFAs, principal axis factor was used as an extraction method to minimise error, and promax rotation was used to indicate the pattern of loadings for this research.

\section{Confirmatory factor analysis The resistance-to-change scale}

In order to address construct validity, CFA was conducted. The results indicated a reasonably acceptable fit for all 17 items and the associated four subscales, with values of 0.87 and 0.89 for Tucker Lewis Index (TLI) and CFI (marginal and very close to the threshold value of 0.9$)$ and an RMSEA of 0.08 . The model chi-square $\left(x^{2}: 266,972\right.$, df: 133) was significant $(p<0.001)$. However, the latter is not a good indication of an acceptable model fit. Subsequently, because of the non-satisfactory fit of the data as shown by the composite consideration of all the relevant fit statistics, an EFA was conducted on the 17-item RTC scale. The SRMR value was 0.0862 , slightly above the suggested threshold of 0.08 .

\section{The Utrecht work engagement scale}

The CFA did not indicate an acceptable fit, with values of 0.831 and 0.856 for TLI and CFI, smaller than the threshold value of 0.9 , and an RMSEA of 0.120 , which indicates a value far from the upper threshold value of 0.08 . The model chisquare $\left(\chi^{2}: 459,338\right.$, df: 116$)$ was significant $(p<0.001)$.

\section{The psychological capital questionnaire (PCQ-24)}

The CFA in this research indicated an almost acceptable fit, with values of 0.872 and 0.889 for TLI and CFI respectively (approximately equal to the threshold value of 0.09) and an RMSEA of 0.080 (equal to the upper threshold of 0.08$)$. The model chi-square $\left(\chi^{2}: 428,417\right.$, df: 183) was significant $(p<0.001)$.

Although the PsyCap and RTC scales show a close to adequate fit, it was decided to confirm the factor structure by conducting an EFA. In the case of UWES, it was necessary to determine the underlying factor structure of the data in this study. A summary of the results follows in Table 1.

Cronbach's $\alpha$ coefficient was used to determine the reliability of measuring instruments (RTC scale, UWES and PCQ-24) as reported in Table 1.

For the RTC scale, both the Kaiser-Meyer-Olkin measure of sampling adequacy (0.861), which was above the recommended threshold of 0.5 , and the Bartlett's test of sphericity, which was significant $(p=0.000)$, indicated that a factor analysis was appropriate for this research. The analysis identified four factors, based on the Kaiser's eigenvalue criterion of eigenvalues greater than one, which explained $62.1 \%$ of variance. The percentage variation explained was $36.4 \%, 10.9 \%, 7.7 \%$ and $7.1 \%$ for the four factors respectively. The results indicated and confirmed a four-structure solution for the RTC scale as proposed in literature.

For the UWES, both the Kaiser-Meyer-Olkin measure of sampling adequacy $(0.933>0.5)$ and the Bartlett's test of sphericity, which was significant $(p=0.000)$, indicated that a factor analysis was appropriate for the UWES. The analysis identified only two factors, namely $\mathrm{Vi} / \mathrm{De}$ (the items that loaded on this factor represented items from both Vi and De) and $\mathrm{Ab}$, based on the Kaiser eigenvalue criterion of eigenvalues greater than one, which explained $62.3 \%$ of the variance. The percentage variation explained was $52.9 \%$ and $9.4 \%$ for the two factors respectively. Although Schaufeli et al. (2008) confirmed a three-dimensional construct in previous studies, the three-factor structure was not considered self-evident in this sample of academics.

For the PCQ-24, both the Kaiser-Meyer-Olkin measure of sampling adequacy (0.920) and the Bartlett's test of sphericity, which was significant $(p=0.000)$, indicated that a factor analysis was appropriate. The resulting factor structure revealed five factors with the three reversed items loading on one factor, forming a construct on their own. Although the remaining items loaded, in general, on the constructs as identified in the Luthans et al. (2007) study, the hope-adapted construct did not emerge clearly. It was decided in this study to exclude the three reverse scored items from further analysis. The overall percentage variation explained was $63 \%$, with $41.9 \%, 9 \%, 6.9 \%$ and $5.2 \%$ for the four factors respectively. 
TABLE 1: Factor loadings and Cronbach's $\alpha$ values for the resistance-to-change scale, Utrecht work engagement scale and psychological capital questionnaire-24.

\begin{tabular}{|c|c|c|c|c|c|c|c|c|}
\hline Construct & $\begin{array}{c}\text { Kaiser-Meyer-Olkin } \\
\text { measure }\end{array}$ & $\begin{array}{c}\text { Bartlett's test of } \\
\text { sphericity }\end{array}$ & $\begin{array}{l}\text { Variance } \\
\text { explained }\end{array}$ & Factor 1 & Factor 2 & Factor 3 & Factor 4 & Cronbach's $\alpha$ \\
\hline \multirow[t]{6}{*}{ RTC } & 0.861 & $p=0.000$ & $62.1 \%$ & $E R$ & $C R$ & $\mathrm{SF}$ & RS & ER 0.72 \\
\hline & - & - & - & 0.635 & 0.404 & 0.526 & 0.305 & RS 0.83 \\
\hline & - & - & - & 0.909 & 0.719 & 0.870 & 0.528 & SF 0.80 \\
\hline & - & - & - & 0.599 & 0.679 & 0.700 & 0.565 & CR 0.73 \\
\hline & - & - & - & 0.396 & 0.692 & 0.569 & 0.499 & - \\
\hline & - & - & - & - & - & - & 0.565 & - \\
\hline \multirow{9}{*}{ UWES } & - & - & - & 0.774 & 0.365 & - & - & Ab 0.87 \\
\hline & - & - & - & 0.868 & 0.603 & - & - & - \\
\hline & - & - & - & 0.453 & 0.486 & - & - & - \\
\hline & - & - & - & 0.824 & 0.784 & - & - & - \\
\hline & - & - & - & 0.868 & 0.705 & - & - & - \\
\hline & - & - & - & 0.860 & 0.396 & - & - & - \\
\hline & - & - & - & 0.808 & 0.731 & - & - & - \\
\hline & - & - & - & 0.462 & 0.701 & - & - & - \\
\hline & - & - & - & 0.343 & 0.429 & - & - & - \\
\hline \multirow[t]{9}{*}{ PCQ-24 } & 0.920 & $p=0.000$ & $63 \%$ & Hope & Efficacy & Resilience & Optimism & Hope 0.87 \\
\hline & - & - & - & -0.363 & 0.490 & 0.375 & 0.602 & Efficacy \\
\hline & - & - & - & -0.765 & 0.846 & 0.331 & 0.712 & 0.89 \\
\hline & - & - & - & -0.657 & 0.768 & 0.402 & 0.605 & Resilience 0.74 \\
\hline & - & - & - & -0.796 & $0.862^{*}$ & $0.539 *$ & 0.499 & Optimism 0.78 \\
\hline & - & - & - & - & 0.594 & 0.594 & - & - \\
\hline & - & - & - & - & 0.737 & 0.571 & - & - \\
\hline & - & - & - & - & 0.375 & 0.373 & - & - \\
\hline & & - & - & - & 0.351 & - & - & - \\
\hline
\end{tabular}

*, Reverse scored.

RTC: resistance to change; UWES: Utrecht work engagement scale; PCQ-24: Psychological capital questionnaire-24; ER, emotional reaction; SF, short term focus; RS, represented by routine seeking; $\mathrm{CR}$, cognitive rigidity; $\mathrm{Vi} / \mathrm{De}$, vigour/dedication; $\mathrm{Ab}$, absorption.

As a Cronbach's $\alpha$ coefficient of 0.7 or more is considered to indicate a reliable scale (Nunnally \& Bernstein, 1994; Pallant, 2010) and because the overall alpha coefficient and that for subscales were deemed to be adequate in this study, no item-reliability analysis was conducted (Terre Blanche \& Durrheim, 2002). All constructs were considered consistent internally. The linear measurement of the inter-relationships between constructs was computed using Pearson's product moment correlations.

\section{Statistical analysis}

Descriptive statistics were calculated to describe the sample characteristics of identified factors within each of the three key constructs, namely mean value, standard deviation, and skewness and kurtosis (De Vos, Delport, Fouche, \& Strydom, 2011; Salkind, 2009).

Correlation analysis was first conducted to test the strength of the relationships between each of the psychological constructs of RTC (RS, ER, SF and CR) and the positive psychological constructs of WE (Vi, De and Ab) and PsyCap (hope, efficacy, resilience and optimism).

Pearson's product moment correlation coefficient $(r)$ was used to calculate the strength of the relationships between variables (Steyn, 2002). Structural equation modelling (SEM) as a multivariate procedure, combining multiple regression and factor analysis, was used to describe the interrelationships between observed variables and the basic goal of providing a quantitative test of the theoretical model as hypothesised (Hair, Black, Babin, \& Anderson, 2010).

In the context of this study, the SEM analysis was performed to test structural paths between the psychological constructs of RTC, WE and PsyCap to test the hypothesised relationships between these constructs as shown in the conceptual model (see Figure 1). Both PsyCap and RTC could be represented as a second-order factor model as both have target coefficient more than 0.9 (Marsh \& Hocevar, 1985). The chi-square values for the first- and second-order models were 266.972 and 267.154 respectively for the RTC instrument, and 428.417 and 429.675 respectively for the PsyCap instrument. The UWES could not be represented by the second-order factor model as the target coefficient was 0.78 . The chi-square values for the first- and second-order models were 2635.9 and 300.7 respectively.

\section{Ethical considerations}

Ethical clearance for this research was obtained from the HEI where the research was conducted.

\section{Results}

The descriptive statistics, namely mean, median, standard deviation, skewness and kurtosis, for each factor obtained in the constructs of the measuring instruments are indicated in Table 2. 
TABLE 2: Mean, median, standard deviation, and skewness and kurtosis.

\begin{tabular}{|c|c|c|c|c|c|c|c|c|c|c|}
\hline Variable & ER & SF & RS & CR & Efficacy & Hope & Resilience & Optimism & Vi/Dei & $A b$ \\
\hline \multicolumn{11}{|l|}{$N$} \\
\hline Valid & 208 & 208 & 208 & 208 & 208 & 208 & 208 & 208 & 208 & 208 \\
\hline Missing & 0 & 0 & 0 & 0 & 0 & 0 & 0 & 0 & 0 & 0 \\
\hline Mean & 3.4147 & 2.6466 & 2.7426 & 3.5685 & 4.4839 & 4.4018 & 4.4357 & 4.1292 & 4.0347 & 4.1662 \\
\hline Median & 3.5000 & 2.5000 & 2.6000 & 3.5000 & 4.1667 & 4.1667 & 4.4000 & 4.0000 & 4.1429 & 4.1429 \\
\hline Std. Deviation & 1.03571 & 0.85452 & 0.83572 & 0.96487 & 0.85347 & 0.76579 & 0.69732 & 0.88733 & 1.00508 & 0.94315 \\
\hline Kurtosis & -0.461 & 0.022 & -0.404 & 0.025 & -0.642 & -0.418 & -0.019 & 0.895 & 0.501 & 0.940 \\
\hline
\end{tabular}

The mean score for RTC ranged from 2.65 to 3.57. The group of academics obtained the highest scores on the CR subscale $(M=3.57 ; \mathrm{SD}=0.97)$, and the lowest scores on the SF subscale $(M=2.65$; $\mathrm{SD}=0.85)$. Standard deviation for the subscales ranged from -0.84 to 1.04 . The skewness values for the RTC scale ranged from -0.09 to 0.35 , thereby falling within the -1 and +1 normality range recommended for these coefficients (Cohen, Manion, \& Morrison, 2011). The kurtosis values ranged from -0.46 to 0.03 , indicating that the distribution of subscales could be considered normal for values between -1 and +1 as recommended for these coefficients (Tredoux \& Durrheim, 2013).

The mean scores for UWES were fairly high and varied from 4.03 to 4.25 . The group of academics obtained the highest score on the $\mathrm{Ab}$ dimension $(M=4.25$; $\mathrm{SD}=0.96)$, and the lowest score on the $\mathrm{Vi} / \mathrm{De}$ dimension $(M=4.03$; $\mathrm{SD}=1.01)$. Standard deviation for the dimensions ranged from 0.96 to 1.0 . The skewness values ranged from -0.51 to -0.52 , thereby falling within the -1 and +1 normality range recommended for these coefficients (Cohen et al., 2011). The kurtosis values ranged from 0.50 to 0.97 , indicating that the distribution of subscales could be considered normal for values between -1 and +1 as recommended for these coefficients (Tredoux \& Durrheim, 2013).

The mean scores for PCQ-24 were all high and ranged from 4.13 to 4.48 . The sample of participants obtained the highest scores on the efficacy sub-construct $(M=4.48 ; \mathrm{SD}=0.85)$, and the lowest scores on the optimism sub-construct $(M=4.13$; $\mathrm{SD}=0.89$ ). Standard deviation for the subscales ranged from 0.70 to 0.89 . The skewness values ranged from -0.24 to 0.34 , thereby falling within the -1 and +1 normality range recommended for these coefficients (Cohen et al., 2011). The kurtosis values ranged from -0.64 to 0.90 , indicating that the distribution of subscales could be considered normal for values between -1 and +1 as recommended for these coefficients (Tredoux \& Durrheim, 2013).

Table 3 indicates inter-relationships between the constructs which were computed using the parametric Pearson's product moment correlation coefficient.

Composite average scores for each construct were calculated by summing the ratings for the set of items associated with each construct and dividing it by the number of items in the set for each case.
Considering the structural coefficients of the final structural model utilising AMOS v23 for the theoretical-based SEM model as indicated in Figure 2, there were a total of five paths, of which three paths were statistically significant.

Model fit statistics indicated the three fit indices, CFI, TLI and RMSEA with values of $0.792,0.782$ and 0.071 respectively. Both CFI and TLI values were below the acknowledged threshold of 0.90 but the RMSEA was considered acceptable as it was below 0.08. Although two of the fit indices did not indicate adequate fit, the non-centrality index, RMSEA, did indicate an adequate fit. The SRMR value was 0.0862 , slightly above the suggested threshold of 0.08 . The size and direction of structural paths were still considered to obtain an insight into the directional relationship between the subscales, dimensions and sub-constructs as postulated in the estimated model. The chi-square (2476.4) with 1217 degrees of freedom was significant $(p=0.000)$. No covariance indicated by modification indices was added to the model to improve model fit as those indicated could not be justified theoretically.

The structural path coefficients from PsyCap to RTC (-0.41), as represented by $\mathrm{H}_{1}$, were statistically significant and indicated a strong negative relationship. Higher levels of PsyCap were therefore related to the lower levels of RTC. From a preventive point of view, it was important to consider previous research indicating that academics demonstrating high levels of efficacy to adapt to organisational change, as well as high levels of resilience to bounce back from setbacks because of challenges during the change process, may reveal positive behaviour that may lead to effective and positive change processes (Luthans et al., 2007).

The path coefficients from PsyCap to Vi/De (0.65) and PsyCap to $\mathrm{Ab}(0.72)$ were statistically significant and indicated a strong positive relationship. There is a positive statistical relationship between PsyCap and WE. The present research supports research that has shown that PsyCap, with each of its psychological resource capacities, demonstrates a positive intentional striving towards WE, flourishing and success, no matter what changes and challenges arise in the work environment. It is important to note that psychological strengths such as WE and PsyCap could possibly contribute significantly to the well-being of ODL academics facing the challenge of change at their work environment.

The path coefficients from RTC to Vi/De (-0.06) and RTC to $\mathrm{Ab}(0.08)$ were not statistically significant and therefore there is no statistical relationship between RTC and WE. 
TABLE 3: Pearson's product moment correlation coefficients on the total constructs of resistance to change, work engagement (Vi/De, Ab) and PsyCap ( $n=208)$.

\begin{tabular}{|c|c|c|c|c|c|c|c|c|c|c|}
\hline Variable & ER & SF & RS & CR & Efficacy & Hope & Resilience & Optimism & $\mathrm{Vi} / \mathrm{De}$ & $A b$ \\
\hline \multicolumn{11}{|l|}{ ER } \\
\hline Pearson's correlation & 1 & - & - & - & - & - & - & - & - & - \\
\hline Sig. (2-tailed) & - & - & - & - & - & - & - & - & - & - \\
\hline$N$ & 208 & - & - & - & - & - & - & - & - & - \\
\hline \multicolumn{11}{|l|}{ SF } \\
\hline Pearson's correlation & $0.627 * *$ & 1 & - & - & - & - & - & - & - & - \\
\hline Sig. (2-tailed) & 0.000 & - & - & - & - & - & - & - & - & - \\
\hline$N$ & 208 & 208 & - & - & - & - & - & - & - & - \\
\hline \multicolumn{11}{|l|}{ RS } \\
\hline Pearson's correlation & $0.582 * *$ & $0.570 * *$ & 1 & - & - & - & - & - & - & - \\
\hline Sig. (2-tailed) & 0.000 & 0.000 & - & - & - & - & - & - & - & - \\
\hline$N$ & 208 & 208 & 208 & - & - & - & - & - & - & - \\
\hline \multicolumn{11}{|l|}{ CR } \\
\hline Pearson's correlation & $0.367 * *$ & $0.322 * *$ & $0.327 * *$ & 1 & - & - & - & - & - & - \\
\hline$N$ & 208 & 208 & 208 & 208 & - & - & - & - & - & - \\
\hline \multicolumn{11}{|l|}{ Efficacy } \\
\hline Pearson's correlation & $-0.217^{* *}$ & $-0.319 * *$ & $-0.462 * *$ & -0.075 & 1 & - & - & - & - & - \\
\hline Sig. (2-tailed) & 0.002 & 0.000 & 0.000 & 0.281 & - & - & - & - & - & - \\
\hline$N$ & 208 & 208 & 208 & 208 & 208 & - & - & - & - & - \\
\hline \multicolumn{11}{|l|}{ Hope } \\
\hline Pearson's correlation & $-0.221 * *$ & $-0.253^{* *}$ & $-0.382 * *$ & -0.102 & $0.715 * *$ & 1 & - & - & - & - \\
\hline Sig. (2-tailed) & 0.001 & 0.000 & 0.000 & 0.143 & 0.000 & - & - & - & - & - \\
\hline$N$ & 208 & 208 & 208 & 208 & 208 & 208 & - & - & - & - \\
\hline \multicolumn{11}{|l|}{ Resilience } \\
\hline Pearson's correlation & $-0.161^{*}$ & -0.110 & $-0.310 * *$ & 0.004 & $0.530 * *$ & $0.637 * *$ & 1 & - & - & - \\
\hline Sig. (2-tailed) & 0.020 & 0.115 & 0.000 & 0.959 & 0.000 & 0.000 & - & - & - & - \\
\hline$N$ & 208 & 208 & 208 & 208 & 208 & 208 & 208 & - & - & - \\
\hline \multicolumn{11}{|l|}{ Optimism } \\
\hline Pearson's correlation & $-0.261 * *$ & $-0.241 * *$ & $-0.272 * *$ & -0.107 & $0.454 * *$ & $0.601 * *$ & $0.489 * *$ & 1 & - & - \\
\hline \multicolumn{11}{|l|}{$\mathrm{Vi} / \mathrm{De}$} \\
\hline Pearson's correlation & $-0.227 * *$ & $-0.279 * *$ & $-0.338 * *$ & -0.057 & $0.372 * *$ & $0.576 * *$ & $0.344 * *$ & $0.550 * *$ & 1 & - \\
\hline Sig. (2-tailed) & 0.001 & 0.000 & 0.000 & 0.416 & 0.000 & 0.000 & 0.000 & 0.000 & - & - \\
\hline$N$ & 208 & 208 & 208 & 208 & 208 & 208 & 208 & 208 & 208 & - \\
\hline \multicolumn{11}{|l|}{$A b$} \\
\hline Pearson's correlation & -0.079 & $-0.194 * *$ & $-0.282 * *$ & -0.062 & $0.445 * *$ & $0.556 * *$ & $0.420 * *$ & $0.343 * *$ & $0.704 * *$ & 1 \\
\hline Sig. (2-tailed) & 0.254 & 0.005 & 0.000 & 0.375 & 0.000 & 0.000 & 0.000 & 0.000 & 0.000 & - \\
\hline$N$ & 208 & 208 & 208 & 208 & 208 & 208 & 208 & 208 & 208 & 208 \\
\hline
\end{tabular}

ER, emotional reaction; SF, short term focus; RS, represented by routine seeking; CR, cognitive rigidity; Vi/De, vigour/dedication; Ab, absorption.

*, Correlation is significant at the 0.05 level.

**, Correlation is significant at the 0.01 level.

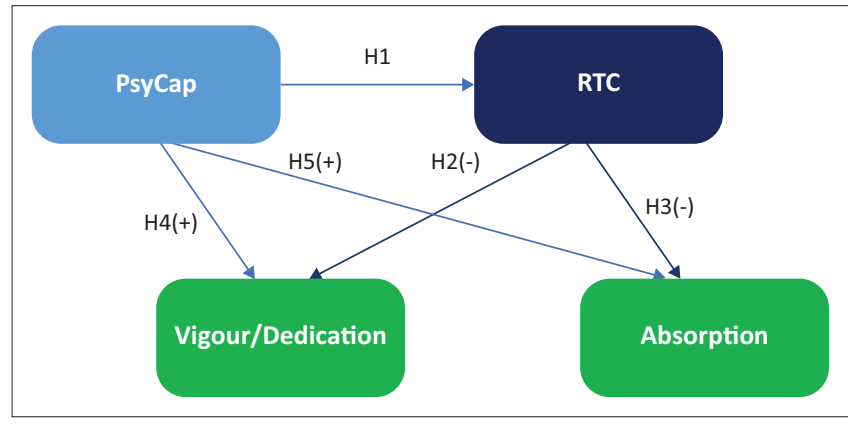

RTC, resistance to change.

FIGURE 2: Conceptual model.

The predictiveness of the model was also assessed in terms of the substantial strength of structural paths or loadings, as opposed to simply achieving statistical significance as reported by Chin (1998). For this study, looking at the predictive structural paths, it was observed that only two of the five standardised regression weights were $>0.60$, with three paths $<0.60$, meaning that each of these measures did not actually account for at least $50 \%$ variance of the underlying latent variable. In addition, two of the standardised paths had estimates below the absolute value of 0.20. According to Chin (1998), the recommended standardised path is at least 0.20 , or above 0.30 , for variables to be considered for interpretation. The regression weights indicated statistically significant structural path coefficients from PsyCap to RTC at $41 \%$ (0.41) and indicated a negative relationship, correlating with previous research findings (Luthanset al., 2007; Porras \& Robertson, 1992). The path coefficient from PsyCap to Vi/De was statistically significant at 65\% (0.65) and from PsyCap to $\mathrm{Ab}$ at $72 \%$ (0.72), and indicated a strongly positive relationship. 


\section{Discussion}

The study aimed to contribute to the research on positive organisational behaviour by offering a model illustrating the dynamic nature of the interrelationships manifested between PsyCap, WE and RTC of academics in a changing ODL work environment.

The objective of this study was to investigate the interrelationship dynamics of the psychological constructs of PsyCap (represented by hope, efficacy, resilience and optimism), WE (represented by Vi, De and Ab) and RTC (represented by RS, ER, SF and CR) as experienced by academics in the changing environment of an ODL University in South Africa.

The results reveal a meaningful positive relationship between the positive psychological constructs of PsyCap and WE and a meaningful negative relationship between the psychodynamic construct RTC and the positive psychological constructs of PsyCap and WE in this profile of academics. Academics may possibly experience emotional components of resistance such as frustration, stress and nervousness because of radical changes and challenges as well as the conscious and unconscious dynamics impacting cognitive, affective and behavioural processes. As the ODL work environment is dynamic and vibrant, academics experience a multitude of challenges at every stage of their professional lives (Baijnath, 2012; Bokor, 2012; Paloff \& Prat, 2011; Picciano, 2006).

The results revealed a strong support for the existence of a significant relationship between the subscales of RTC, resulting in these academics refusing, denying or rejecting the change, and the more negative these feelings are, the stronger are the emotional reactions, directly impacting the well-being. The results also indicate high levels of routineseeking. However, the results reveal that the academics possess a high level of intentional behaviour as well as high levels of understanding of the reasons for these changes. The perspective of systems psychodynamics may therefore reveal new insights into the complexity of the conscious and unconscious dynamics taking place in this work environment. According to Heinrich (2004), this may assist individual to perceive or understand the changes as a threat or a challenge which in this sample of academics may lead them to being willing to change.

The results suggest that participants do consider the longterm benefits of change to be important and are willing to act in response to a change in the environment. Therefore, from a positive work and organisational psychological perspective, RTC or the reaction to change may involve new ways of thinking and result in new behaviours. Although the assumption that acceptance of change is good, whereas resistance is bad (Battilana \& Casciaro, 2013; Hon, Bloom, \& Crant, 2014), passive responses, even if positive, may retard change, whereas active responses, even if negative, may sometimes facilitate adjustments in the long run by clarifying problems with the change (Oreg et al., 2018). This implies that academics' experience of change with regard to the perceived benefits of the change and challenges can have a positive effect on their WE and flourishing.

The data support that the academics possess a high level of WE, measured against the norms provided by Schaufeli and Bakker (2003) and the results suggest a two-factor model of $\mathrm{WE}(\mathrm{Vi} / \mathrm{De}$ and $\mathrm{Ab})$, as in prior research studies (Naudé \& Rothmann, 2004; Nerstad, Richardsen, \& Martinussen, 2010; Schaufeli et al., 2008). The results of this research reveal that these ODL academics are energetic, see work as meaningful, stimulating and something that they want to concentrate on, despite the challenges of ODL work environment. High levels of WE imply a positive, energetic and fulfilling workrelated state of mind (Schaufeli et al., 2002). Because WE cannot be regarded as a skill that could be developed, but is rather an affective-motivational state, it is suggested that organisations need to create working environments that could cultivate work engagement and well-being.

Furthermore, the results reveal fairly high levels of PsyCap and WE that may possibly indicate high levels of emotional well-being in these academics, and flourishing could include the presence of high levels of emotional, psychological and social well-being. Flourishing employees function optimally in their work environment and according to Rothmann (2013) this manifests through multi-dimensional indicators such as flourishing, hope, efficacy, resilience and optimism.

As significant hope was revealed in this sample of academics, it may contribute positively to PsyCap. The results revealed high levels of hope as well as WE. Roemer and Harris (2018) reported a strong correlation between WE and PsyCap in a sample of employees in a variety of professions such as education, administration, health, engineering, accounting and human resources. They similarly reported that the dimension of hope showed maximum predictive variance in explaining hope. This in turn suggests that academics in this study, in an ODL environment as well as in various other professions, tend to be more energised to persist in achieving their particular goals, as hope is closely related to constructs such as efficacy, optimism, resilience and generalised well-being and positive work and organisational psychology (Larson \& Luthans, 2006; Luthans et al., 2007).

The results in this study reveal that the academics possess fairly low levels of resiliency. The results of this study are consistent with scholars such as Luthans (2002) and Roemer and Harris (2018), who conclude that although resiliency has been recognised in positive psychology movement (Masten, 2001), it goes beyond simple adaptation and is reactive rather than proactive. These academics possess an adequate level of optimism, and Luthans, Luthans and Luthans (2004) report optimism to be more closely associated with positive psychology than other constructs. 
In terms of structural equation model methods, implemented to test the measurement and structural models, the results revealed an acceptable fit with the data. The results revealed a significant negative relationship between PsyCap and RTC in this sample of ODL academics. It is important to note that a negative relationship was also found between PsyCap and RTC in the correlational analysis of this research. Similar research conducted by Beal III et al. (2013) and Saruhan (2013) suggested that employees who reported high levels of RTC reported low levels of PsyCap.

In conclusion, the results reveal a strong support for the existence of a significant interrelationship between RTC, WE and PsyCap in academics at the ODL HEI. PsyCap was the strongest predictor of WE, whilst the relationship between RTC and Psycap was a moderately negative one.

\section{Practical implications}

Distance learning academics often feel overwhelmed in the changing work environment, as they are expected to perform complex tasks, often in isolation, and experience a lack of role clarity whilst navigating the demands of the changing higher education environment. Major change challenges, such as globalisation and technological innovations, may create new opportunities to involve academics actively in the process of change to enhance and reinforce their positive work and organisational psychological functioning. An action plan, focusing on opportunities for academic as well as for positive organisation, and embodying the principles of fairness and the favourable aspects of change, should be implemented. This has the potential to have a positive impact on commitment to change and challenge.

Academics are expected to take responsibility for their own personal development, and as job resources are positively related to WE, the organisation needs to implement action plans to ensure the availability of physical, cognitive and emotional resources. The organisation should create an organisational climate that is supportive and conducive to fair, trusting employee relationships and vibrant communication channels, and this would contribute to greater WE and increased psychological well-being. Positive work and organisational psychological functioning interventions implemented at the ODL HEI would help to enhance employee well-being and the flourishing of employees.

On a practical level, leadership training should acknowledge system psychodynamics in organisations and create awareness around the topics of restraint, destruction and anxieties within organisations. Leadership training should use applied systems psychodynamic interventions to create increased awareness of roles, authorisation, ownership and professionalism by using self-reflective approaches, reflexivity training and the definition of boundaries.

Psychological well-being could be enhanced by decreasing the workload of academics, ensuring variety in their tasks and providing different learning opportunities and autonomy in their jobs. Job resources, referring to physical, social or organisational aspects of the job that may, for example, reduce job demands and the associated physiological and psychological costs, should be increased. Furthermore, the ODL HEI could actively, through strategies and leadership, eliminate negative attitudes and behaviour as well as any institutional barriers that may prevent the optimal functioning and engagement of the ODL academic.

Interventions to increase state-like PsyCap are assumed to produce synergy effects leading to higher efficiency. A healthy workplace, availability of resources, support and WE seems to contribute in promoting the well-being of employees (Keyes, 2007). Research indicated that face-toface and web-based interventions could enhance an individual's level of PsyCap (Luthans et al., 2008, 2010). This malleability is an important characteristic because organisations might be able to influence and develop PsyCap of their employees.

A continued professional development (CPD) programme aimed specifically at equipping ODL academics with necessary competencies, skills and knowledge to deal with change and challenges could be implemented at the HEI. This may also inculcate adequate positive psychological behaviour so that academics are able to function optimally in the changing ODL work environment and flourish.

\section{Limitations and recommendations}

The study had various limitations. Firstly, because of the relatively small sample applied in this study, the results of this study cannot be generalised to the overall population of academics. A larger sample with more representatives would have been desirable because this would have made it possible to generalise the results. As only academics in an ODL institution participated in this study, the future studies on the interrelationships between RTC, WE and PsyCap should consider larger samples from more diverse organisations in order to increase the generalisability of results.

Secondly, three specific measuring instruments, namely the RTC scale (Oreg, 2006), the UWES (Schaufeli \& Bakker, 2003) and the PCQ-24 (Luthans et al., 2007) were used in this study. As only one instrument for each construct was used, different measuring instruments might have revealed different results.

Thirdly, another limitation pertaining to the study was the use of a cross-sectional design. This limits the inference and confirmation of causal relationships between RTC, WE and PsyCap. It is recommended that longitudinal research be conducted to undertake further investigation into the drivers of RTC, WE and PsyCap.

This study delivered interesting and meaningful results, and it should be noted that certain limitations may be overcome 
by the future research studies, especially empirical research that could extend beyond the scope of this study. This may contribute to policy development on ODL staff development, health and well-being as well as interventions to support WE and PsyCap of academics.

\section{Conclusion}

This study empirically confirmed that dynamic interrelationships exist between an academic's RTC (represented by routine seeking, emotional reaction, shortterm focus and cognitive rigidity), WE (represented by vigour, dedication and absorption) and PsyCap (represented by hope, efficacy, resilience and optimism), and that this produces individuals with different levels of psychological and psychodynamic behaviour that informs optimal organisational functioning in a changing work environment. Furthermore, academics displaying a particular level of positive psychological behaviour are able to adapt to changes and are more engaged, hopeful, efficacious, resilient and optimistic, which in turn influence their work performance. Therefore, the interrelationships of RTC, WE and PsyCap of ODL academics in a changing work environment relates positively towards the reduction of RTC as well as the flourishing, positive work and organisational psychological functioning and well-being of academics.

\section{Acknowledgements}

This research was conducted as part of the first author's (J.C.D.) doctoral degree, and completed at the University of South Africa (Unisa), South Africa.

\section{Competing interests}

The authors declare that they have no financial or personal relationship(s) that may have inappropriately influenced the writing of this article.

\section{Authors' contributions}

This article uses the doctoral research of J.C.D. (Unisa) as its basis. F.C. was the supervisor and A.B. its co-supervisor.

\section{Funding information}

This research received no specific grant from any funding agency in the public, commercial or not-for-profit sectors.

\section{Data availability statement}

Data sharing is not applicable to this article as no new data were created or analysed in this study.

\section{Disclaimer}

The views and opinions expressed in this article are those of the authors and do not necessarily reflect the official policy or position of any affiliated agency of the authors.

\section{References}

Abramovici, M., Göbel, J.C., \& Neges, M. (2015). Smart engineering as enabler of the 4 th industrial revolution. In Integrated systems, innovations and applications. Springer.

Alarcon, G.M., Bowling, N.A., \& Khazon, S. (2013). Great expectations: A meta-analytic examination of optimism and hope. Personality and Individual Differences, 54(7), 821-827. https://doi.org/10.1016/j.paid.2012.12.004

Arbuckle, J.L. (2006). Amos (Version 7.0) [Computer Program]. Chicago, IL: SPSS.

Arinto, P.B. (2013). A framework for developing competencies in open and distance learning. International Review of Research in Open and Distance Learning, 4(1) 167-185. https://doi.org/10.19173/irrodl.v14i1.1393

Avey, J.B., Hughes, L.W., Norman, S.M., \& Luthans, K.W. (2008). Using positivity, transformational leadership and empowerment to combat employee negativity. Leadership and Organisational Development Journal, 29, 110-126.

Avey, J.B., Luthans, F., \& Jensen,S.M. (2009). Psychological capital: A positive resource for combating employee stress and turnover. Human Resource Management, 48, 677-693. https://doi.org/10.1002/hrm.20294

Avey, J.B., Reichard, R.J., Luthans, F., \& Mhatre, K.H. (2011). Meta-analysis of the impact of positive psychological capital on employee attitudes, behaviours and performance. Human Resource Development Quarterly, 23(2), 127-152. https:// doi.org/10.1002/hrdq.20070

Baijnath, N. (2012). An organisational architecture for a digital future - A discussion document. Pretoria: University of South Africa.

Bakker, A.B., Albrecht, S.L., \& Leiter, M.P. (2011). Key questions regarding work engagement. European Journal of Work and Organizational Psychology, 20(1), 4-28. https://doi.org/10.1080/1359432X.2010.485352

Bakker, A.B., \& Demerouti, E. (2008). Towards a model of work engagement. Career Development International, 13(3), 209-223. https://doi.org/10.1108/13620430 810870476

Bakker, A.B., Demerouti, E., \& Burke, R. (2009). Workaholism and relationship quality: A spillover-crossover perspective. Journal of Occupational Health Psychology, 14(1), 23-33. https://doi.org/10.1037/a0013290

Bakker, A.B., Gierveld, J.H., \& Van Rijswijk, K. (2006). Succesfactoren bij vrouwelijke schoolleiders in het primair onderwijs: Een onderzoek naar burnout, bevlogenheid en prestaties [Success factors among female school principals in primary teaching: A study on burnout, work engagement, and performance]. Diemen: Right

Bakker, A.B., \& Schaufeli, W.B. (2008). Positive organisational behaviour: Engaged employees in flourishing organisations. Journal of Organisational Behaviour, 29, 147-154. https://doi.org/10.1002/job.515

Bakker, A.B., Schaufeli, W.B., Leiter, M.P., \& Taris, T.W. (2008). Work engagement: An emerging concept in occupational health psychology. Work and Stress, 22(3), 187-200. https://doi.org/10.1080/02678370802393649

Barkhuizen, N., Rothmann, S., \& Van de Vijver, F.J.R. (2014). Burnout and work engagement of academics in higher education institutions: Effects of dispositional optimism. Stress and Health, 30(4), 322-332. https://doi.org/10.1002/smi.2520

Bates, T. (2014). Teaching in a digital age. Retrieved from http://www.tonybates. ca/2014/08/10/choosingteaching-methods-for-a-digital-age/\#sthash.OsoKOdTR.dpuf.

Battilana, J., \& Casciaro, T. (2013). Overcoming resistance to organisational change: Strong ties and affective cooptation. Management Science, 59, 819-836. https:// doi.org/10.2307/23443813

Beal III, L., Stavros, J.M., \& Cole, M.L. (2013). Effect of psychological capital and resistance to change on organisational citizenship behaviour. South African Journal of Industrial Psychology, 39(2), 1-11. https://doi.org/10.4102/sajip. v39i2.1136

Bokor, J. (2012). University of the future. A thousand year old industry on the cusp of profound change. Retrieved from http://www.ey.com/Publication/vwLUAssets/ Universityofthefuture/\$File/Universityofthefuture2012.pdf.

Bruque, S., Moyano, J., \& Eisenberg, J. (2008). Individual adaptation to IT-induced change: The role of social networks. Journal of Management Information Systems, 25,177-206.

Calitz, T.M. (2013). An empowerment programme to regain positive work engagement for social workers in the North West Province (Doctoral dissertation). North-West University, Potchefstroom.

Chin, W.W. (1998). Issues and opinions on structural equation modeling. MIS Quarterly, 22(1), 1-10.

Cilliers, F., \& Koortzen, P. (2005). Working with conflict in teams - The CIBART model. HR Future, 10(1), 52-53.

Cloete, A.L. (2017). Technology and education: Challenges and opportunities. HTS Theological Studies, 73(4), 1-7. https://doi.org/10.4102/hts.v73i4.4589

Coetzee, M., \& De Villiers, M. (2010). Sources of job stress, work engagement and career orientations of employees in a South African financial institution. Souther African Business Review, 14(1), 27-57.

Coetzer, W.J., \& Rothmann, S. (2007). A psychometric evaluation of measures of affective well-being in an insurance company. South African Journal of Industrial Psychology, 33(2), 7-15. https://doi.org/10.4102/sajip.v33i2.372

Cohen, L., Manion, L., \& Morrison, K. (2011). Research methods in education (6th edn.). Abingdon: Routledge.

Conley, C. (2007). Peak: How great companies get their mojo from Maslow. San Francisco, CA: Jossey-Bass. 
Del Val, M.P., \& Fuentes, C.M. (2003). Resistance to change: A literature review and empirical study. Management Decision, 41(2), 148-155. https://doi. empirical study. Management
org/10.1108/00251740310457597

Desrumaux, P., Lapointe, D., Ntsame Sima, M., Boudrias, J.S., Savoie, A., \& Brunet, L. (2015). The impact of job demands, climate and optimism on well-being and distress at work: What are the mediating effects on basic psychological need satisfaction? European Review of Applied Psychology, 65(4), 179-188. https://doi. satisfaction? European Review of $\mathrm{Ap}$
$\mathrm{org} / 10.1016 / \mathrm{j}$.erap.2015.06.003

De Vos, A., Delport, C., Fouche, C., \& Strydom, H. (2011). Research at grass roots: A primer for the social science and human professions. Pretoria: Van Schaik.

De Vries, M.K. (2009). The shadow side of leadership. Human Capital Review, 2(7) Retrieved from www.humancapitalreview.org

De Waal, J.J.P., \& Pienaar, J. (2013). Towards understanding causality between work engagement and psychological capital. South African Journal of Industria Psychology, 39(2), 1-10. https://doi.org/10.4102/sajip.v39i2.1113

Diedericks, E., \& Rothmann, S. (2013). Flourishing of information technology professionals: The role of work engagement and job satisfaction. Journal of Psychology in Africa, 23(1), 55-64. https://doi.org/10.1080/14330237.2013.10820618

Faul, F., Erdfelder, E., Buchner, A., \& Lang, A.G. (2009). Statistical power analyses using G*Power 3.1: Tests for correlation and regression analyses. Behaviour Research G*Power 3.1: Tests for correlation and regression analyses. Behaviou

Fida, R., Paciello, M., Tramontano, C., Barbaranelli, C., \& Farnese, M.L. (2015). 'Yes, I can': The protective role of personal self-efficacy in hindering counterproductive work behavior under stressful conditions. Anxiety, Stress, \& Coping, 28(5), 479-499. https://doi.org/10.1080/10615806.2014.969718

Golom, F.D. (2017). Debra A. Noumair: Understanding organizational life beneath the surface. In D.B. Szabla, W.A. Pasmore, M.A. Barnes, \& A.-N. Gipson (Eds.), The Palgrave handbook of organizational change thinkers (pp. 1-13). Cham, $\mathrm{CH}$ : Springer.

Greyvenstein, H., \& Cilliers, F. (2012). Followership's experiences of organisational leadership: A systems psychodynamic perspective. South African Journal of Industrial Psychology, 38(2), 1-10. https://doi.org/10.4102/sajip.v38i2.1001

Guasch, T. Alvarez, I., \& Espasa, A. (2010). University teacher competencies in a virtual teaching/learning environment: Analysis of a teacher training experience. Teaching and Teacher Education, 26(2), 199-206. https://doi.org/10.1016/j. tate.2009.02.018

Hair, J., Black, W., Babin, B., \& Anderson, R. (2010). Multivariate data analysis. Pearson, NJ: Pearson Education.

Heinrich, T. (2004). Resistance to change - Does age matter? Predicting negative attitudes towards organisational change. London: Turnshare.

Henning, S. (2009). Towards a system psychodynamic model of psychological wellness (Doctoral thesis). University of South Africa, Pretoria.

Heydenrych, J.F., \& Prinsloo, P. (2010). Revisiting the five generations of distance education: Quo vadis? Progressio, 32(1), 5-26.

Hobfoll, S.E. (2002). Social and psychological resources and adaptation. Review of General Psychology, 6, 307-324. https://doi.org/10.1037/1089-2680.6.4.307

Hon, A.H., Bloom, M., \& Crant, J.M. (2014). Overcoming resistance to change and enhancing creative performance. Journal of Management, 40, 919-941. https:// doi.org/10.1177/0149206311415418

Inzlicht, M., Schmeichel, B.J., \& Macrae, C.N. (2014). Why self-control seems (but may not be) limited. Trends in Cognitive Sciences, 18(3), 127-133. https://doi. org/10.1016/j.tics.2013.12.009

Kearsley, G. (2000). Online education: Learning and teaching in cyberspace. Belmont, CA: Wadsworth/Thomson Learning.

Kerlinger, F.N. (1986). Foundations of behavioural research (3rd edn.). Orlando, FL: Harcourt Brace Jovanovich College Publishers.

Keyes, C.L.M. (2007). Promoting and protecting mental health as flourishing: A complementary strategy for improving national mental health. American Psychologist, 62, 95-108.

Keyes, C.L.M., \& Annas, J. (2009). Feeling good and functioning well: Distinctive concepts in ancient philosophy and contemporary science. Journal of Positive Psychology, 4, 197-201. https://doi.org/10.1080/17439760902844228

Koortzen, P., \& Cilliers, F. (2002). The psychoanalytical approach to team development. In R.L. Lowman (Ed.), Handbook of organizational consulting psychology (pp. 260-284). San Francisco, CA: Jossey-Bass.

Kuanda, L. (2012). Curriculum internationalisation in an African context. University World News, 242. Retrieved from http://www.universityworldnews.com/article. php?story=20121003103951872.

Larson, M., \& Luthans, F. (2006). Potential added value of psychological capital in predicting work attitudes. Journal of Leadership and Organisational Studies, 13, 45-62. https://doi.org/10.1177/10717919070130020601

Leedy, P.D., \& Ormrod, J.E. (2013). Practical research, planning and design. London: Pearson.

Leibowitz, B., Bozalek, V., Van Schalkwyk, S., \& Winberg, C. (2015). Institutional context matters: The professional development of academics as teachers in South Africa. Higher Education, 69, 315-330.

Lewin, K. (1947/1959). Group decisions and social change. In T.M. Newcomb \& E.L. Hartley (Eds.). Readings in social psychology (pp. 197-211). New York: Holt.

Luthans, F. (2002). The need for and meaning of positive organisational behaviour. Journal of Organisational Behaviour, 23, 659-706. https://doi.org/10.1002/job.165

Luthans, F., Avey, J.B., Avolio, B.J., \& Peterson, S.J. (2010). The development and resulting performance impact of positive psychological capital. Human Resource
Development Quarterly, 21(1), 41-67. https://doi.org/10.1002/hrdq.20034
Luthans, F., Avey, J.B., \& Patera, J.L. (2008). Experimental analysis of a web-based training intervention to develop positive. Academy of Management Learning \& Education, 7(2), 209-221. https://doi.org/10.5465/AMLE.2008.32712618

Luthans, F., Avolio, B.J., Avey, J., \& Norman, S.M. (2007). Positive psychological capital: Measurement and relationship with performance and satisfaction. Personnel Psychology, 60, 541-572. https://doi.org/10.1111/j.1744-6570.2007.00083.x

Luthans, F., Luthans, K.W., \& Luthans, B.C. (2004). Positive psychological capital: Beyond human and social capital. Business Horisons, 47(1), 45-50. https://doi. org/10.1016/j.bushor.2003.11.007

Luthans, F., Norman, S.M., Avolio, B.J., \& Avey, J.B. (2008). The mediating role of psychological capital in the supportive organisational climate - Employe performance relationship. Journal of Organisational Behaviour, 29, 219-238. https://doi.org/10.1016/j.bushor.2003.11.007

Luthar, S.S., \& Cicchetti, D. (2000). The construct of resilience: Implications for intervention and social policy. Development and Psychopathology, 12, 867-886.

Masten, A.S. (2001). Ordinary magic: Resilience processes in development. American Psychologist, 56, 227-238.

Mauno, S., Kinnunen, U., \& Ruokolainen, M. (2007). Job demands and resources as antecedents of work engagement: A longitudinal study. Journal of Vocational Behaviour, 70, 149-171.

Marsh, H.W., \& Hocevar, D. (1985). Application of confirmatory factor analysis to the study of self-concept: First- and higher-order factor models and their invariance across groups. Psychological Bulletin, 97(3), 562-582. https://doi.org/10.1037/ 0033-2909.97.3.562

Martin, R. (2007). Online education and training: Well-founded pedagogy or state corporate interest? South African Journal of Higher Education, 21(3), 473-484.

Mayer, C.H. (2011). The sense of coherence in trans-cultural management. Münster: Waxmann.

Mayer, C.H., \& Surtee, S. (2015). The leadership preferences of women leaders working in higher education. Generos, Multidisciplinary Journal of Gender Studies, 4(19), 612-636. https://doi.org/10.17583/generos.2015.1320

Miner, M., Bickerton, G., Dowson, M., \& Sterland, S. (2015). Spirituality and work engagement among church leaders. Mental Health, Religion \& Culture, 18(1), 57-71. https://doi.org/10.1080/13674676.2014.1003168

Naudé, J.L.P., \& Rothmann, S. (2004). The validation of the Utrecht Work Engagement Scale for emergency medical technicians in Gauteng. South African Journal of Economic and Management Sciences, 7(3), 459-468. https://doi.org/10.4102/ sajems.v7i3.1356

Nerstad, C.G.L., Richardsen, A.M., \& Martinussen, M. (2010). Factorial validity of the Utrecht Work Engagement Scale (UWES) across occupational groups in Norway. Scandinavian Journal of Psychology, 51(4), 326-333. https://doi.org/10.1111/ j.1467-9450.2009.00770.x

Nunnally, J., \& Bernstein, I.H. (1994). Psychometric theory (3rd edn.). New York: McGraw-Hill.

Oreg, S. (2003). Resistance to change: Developing an individual difference measure. Journal of Applied Psychology, 88(4), 680-693. https://doi.org/10.1037/00219010.88.4.680

Oreg, S. (2006). Personality, context and resistance to organisational change. European Journal of Work and Organisational Psychology, 15(1), 73-101. https://doi. org/10.1080/13594320500451247

Oreg, S., Bartunek, J.M., Lee, G., \& Do, B. (2018). An affect-based model of recipients' responses to organisational change events. Academy of Management Review, 43(1), 65-86. https://doi.org/10.5465/amr.2014.0335

Oreg, S., Michel, A., \& By, R.T. (Eds.). 2013. The psychology of organisational change: Viewing change from the employee's perspective. Cambridge: Cambridge University Press.

Oreg, S., Vakola, M., \& Armenakis, A.A. (2011). Change recipients' reactions to organisational change: A sixty-year review of quantitative studies. Journal of Applied Behavioural Science, 47, 461-524. https://doi.org/10.1177/0021886310396550

Pallant, J. (2010). SPSS survival manual: A step by step guide to data analysis using SPSS for Windows (version 12) (2nd edn.). New York: McGraw-Hill.

Paloff, P., \& Pratt, K. (2011). The excellent online instructor: Strategies for professiona development. San Francisco, CA: Wiley.

Palmer, I., Dunford, R., \& Akin, G. (2009). Managing organisational change: A multiple perspectives approach (2nd edn.). New York: McGraw-Hill.

Panda, S., \& Mishra, S. (2007). E-learning in a mega open university: Faculty attitude, barriers, and motivators. Educational Media International, 14(1), 324-338. https://doi.org/10.1080/09523980701680854

Picciano, A.G. (2006). Online learning: Implications for higher education pedagogy and policy. Journal of Thought, 41, 75-94.

Poalses, J., Joubert, J.P.R., Bezuidenhout, A., \& Nienaber, H. (2014). College of economic and management sciences occupational stress and risk assessment. Pretoria: University of South Africa.

Porras, J.I., \& Robertson, P.J. (1992). Organisational development: Theory, practice and research. In M.D. Dunnette \& L.M. Hough (Eds.). Handbook of industrial and organisational psychology (2nd edn, Vol. 3, pp. 719-822). Palo Alto, CA: Consulting Psychologists Press.

Rice, J.K. (2009). The role of tenure as a moderator to work engagement and job satisfaction (Master's thesis). San José State University, San Jose, CA.

Rodda, J. (2007). A multilevel examination of employee reactions to organisational change (PhD dissertation). DePaul University, Chicago, IL. 
Rodriguez, C.O. (2013). Two distinct course formats in the delivery of connectivist: MOOCS. Turkish Online Journal of Distance Education, 14, 66-80.

Roemer, A., \& Harris, C. (2018). Perceived organisational support and well-being: The role of psychological capital as a mediator. South African Journal of Industrial Psychology, 44(0), a1539. https://doi.org/10.4102/sajip.v44i0.1539

Rothmann, S. (2013). From happiness to flourishing at work: A Southern African perspective. In M.P. Wissing (Ed.), Well-being research in South Africa: Crosscultural advances in positive psychology (Vol. 4, pp. 123-152). Dordrecht: Springer.

Rothmann, S. (2017). Employee engagement. In L.G. Oades, M.F. Steger, A.D. Fave \& J. Passmore (Eds.), The Wiley Blackwell handbook of the psychology of positivity and strengths-based approaches at work (pp. ). Hoboken, NJ: Wiley.

Rothmann, S., \& Cilliers, F. (2007). Present challenges and some critical issues for research in industrial/organisational psychology in South Africa. South African Journal of Industrial Psychology, 33(1), 8-17. https://doi.org/10.4102/sajip.v33i1.262

Saruhan, N. (2013). Organisational change: The effects of trust in organisation and psychological capital during change process. Journal of Business Economics and Finance, 2(3), 13-35.

Saks, A.M. (2011). Workplace spirituality and employee engagement. Journal of Management, Spirituality \& Religion, 8(4), 317-340. https://doi.org/10.1080/147 66086.2011.630170

Salanova, M., \& Schaufeli, W.B., (2008). A cross-national study of work engagement as a mediator between job resources and proactive behaviour. The Internationa org/10.1080/09585190701763982

Salkind, J.N. (2009). Exploring research (7th edn.). Upper Saddle River, NJ: Pearson.

Schaufeli, W.B., \& Bakker, A.B. (2003). Utrecht work engagement scale. Preliminary manual. Utrecht: Occupational Health Psychology Unit, Utrecht University. PMC Id: PMC1765719.

Schaufeli, W.B., Bakker, A.B., \& Van Rhenen, W. (2008). How changes in job demands and resources predict burnout, work engagement, and sickness absenteeism. Journal of Organisational Behaviour, 30(7), 893-917. https://doi.org/10.1002/ job.595

Scott, I., Yeld, I., \& Hendry, J. (2007). A case for improving teaching and learning in South African higher education. Pretoria: The Council on Higher Education.

Seale, O., \& Cross, M. (2016). Leading and managing in complexity: The case of South African deans. Studies in Higher Education, 41(8), 1514-1532. https://doi.org/10. 1080/03075079.2014.988705

Seligman, M.E.P., \& Csikszentmihalyi, M. (2000). Positive psychology: An introduction. American Psychologist, 55(1), 5-14.

Söderström, T., From, J., Lövqvist, J., \& Törnquist, A. (2012). The transformation from distance to online education: Perspectives from the educational management horizon. The European Journal of Open, Distance and E-learning, 1, 1-9.

Sonnentag, S., Mojza, E.J., Binnewies, C., \& Scholl, A. (2008). Being engaged at work and detached at home: A week-level study on work engagement, psychological detachment, and affect. Work \& Stress, 22, 257-276. https://doi.org/10. 1080/02678370802379440
Souri, H., \& Hasanirad, T. (2011). Relationship between resilience, optimism and psychological well-being in students of medicine. Procedia - Social and Behavioral Sciences, 30, 1541-1544. https://doi.org/10.1016/j.sbspro.2011. Behaviora
10.299

Spreitzer, G.M., Lam, C.F., \& Fritz, C. (2010). Engagement and human thriving: Complementary perspectives on energy and connections to work. In A.B. Bakker \& M.P. Leiter (Eds.), Work engagement: A handbook of essential theory and $\&$ M.P. Leiter (Eds.), Work engagement: A handbook
research (pp. 132-146). New York: Psychology Press.

SPSS. (2003). SPSS 12.0 for Windows. Chicago, IL: SPSS

Stanley, D.J., Meyer, J.P., \& Topolntsky, L. (2005). Employee cynicism and resistance to organisational change. Journal of Business and Psychology, 19(4), 429-459.

Steyn, H. (2002). Practical significant relationships between two variables. South African Journal of Industrial Psychology, 28(3), 10-15.

Storm, K. (2002). Burnout and work engagement in the South African Police Service (Unpublished doctoral thesis). North-West University, Potchefstroom.

Storm, K., \& Rothmann, S. (2003). A psychometric analysis of the Utrecht work engagement scale in the South African Police Service. South African Journal of Industrial Psychology, 29(4), 62-70. https://doi.org/10.4102/sajip.v29i4.129

Swart, J.J., \& Rothmann, S. (2012). Authentic happiness of managers, and individual and organisational outcomes. South African Journal of Psychology, 42(4), 492508. https://doi.org/10.1177/008124631204200404

Terre Blanche, M., \& Durrheim, K. (2002). Research in practice: Applied methods for the social sciences. Cape Town. South Africa: UCT Press.

Tredoux, C., \& Durrheim, K. (2013). Numbers, hypotheses, and conclusions (2nd edn.). Cape Town: UCT Press.

Van Den Heuvel, S., \& Schalk, R. (2009). The relationship between fulfilment of the psychological contract and resistance to change during organisational transformation. Social Science Information, 48(2), 283-313. https://doi.org/10. 1177/0539018409102415

Van Der Walt, F. (2018). Workplace spirituality, work engagement and thriving at work. South African Journal of Industrial Psychology, 44(0), a1457. https://doi. org/10.4102/sajip.v44i0.1457

Weinberg, A., \& Cooper, C. (2007). Surviving the workplace: A guide to emotional wellbeing. London: Thomson.

Weller, M. (2002). Delivering learning on the Net: The why, what and how of online education. London: Kogan Page.

Wissing, M.P., Potgieter, J.C., Guse, T., Khumalo, I.P., \& Nel, L. (2014). Towards flourishing: Contextualising positive psychology. Pretoria: Van Schaik.

Youssef, C., \& Luthans, F. (2012). Psychological capital: Meaning, finding and future directions. In K.S. Cameron \& G.M. Spreitzer (eds.). The Oxford handbook of positive organisational scholarship (pp.17-27). New York, NY: Oxford University Press.

Zhonggen, Y. (2015). Blended learning over decades. International Journal of Information and Communication Technology Education, 11(3), 1-19. 